\title{
Pengaruh Kepemimpinan Transformasional dan Kepemimpinan Transaksional Terhadap Kinerja Pegawai Dengan Locus of Control Sebagai Variabel Moderating
}

\author{
Jufrizen \\ Afni Sasqia Putri Lubis
Program Studi Manajemen, Universitas Muhammadiyah Sumatera Utara Medan, Indonesia Jl. Kapten Muchtar Basri No. 3 Medan, Sumatera Utara 20217 \\ Email: jufrizen@umsu.ac.id
}

\begin{abstract}
Abstrak. Tujuan penelitian ini adalah Untuk mengetahui dan menganalisis pengaruh kepemimpinan transformasional dan kepemimpinan transaksional terhadap kinerja pegawai dimoderasi oleh Locus Of Control pada pegawai kantor wali kota Medan baik secara langsung maupun tidak langsung. Pendekatan yang digunakan dalam penelitian ini adalah pendekatan asosiatif. Populasi dalam penelitian ini adalah seluruh pegawai kantor wali kota Medan sebanyak 89 orang sedangkan sampel dalam penelitian ini seluruh pegawai kantor wali kota Medan sebanyak 89 orang menggunakan sampel jenuh. Teknik pengumpulan data dalam penelitian ini menggunakan teknik wawancara, studi dokumentasi, observasi, dan angket. Teknik analisis data dalam penelitian ini menggunakan partial least square - structural equestion model (PLS-SEM). Pengolahan data dalam penelitian ini menggunakan program software PLS (Partial Least Square) versi 3.0. Hasil penelitian ini membuktikan bahwa secara langsung kepemimpinan transformasional, kepemimpinan transaksional dan Locus of Control berpengaruh signifikan terhadap kinerja pegawai dan secara tidak langsung Locus of Control tidak memoderasi pengaruh kepemimpinan transformasional dan kepemimpinan transaksional terhadap kinerja pegawai pada kantor wali kota Medan.
\end{abstract}

Kata Kunci : Kepemimpinan Transformasional, Kepemimpinan Transaksional, Locus of Control, Kinerja

\begin{abstract}
The purpose of this study was to determine and analyze the effect of transformational leadership and transactional leadership on employee performance moderated by the Locus of Control of Medan mayor's office employees both directly and indirectly. The approach used in this research is an associative approach. The population in this study were all employees of Medan mayor's office as many as 89 people while the sample in this study all employees of Medan mayor's office were 89 people using saturated samples. Data collection techniques in this study used interview techniques, documentation studies, observations, and questionnaires. Data analysis techniques in this study used partial least square - structural equestion model (PLS-SEM). Data processing in this study uses PLS (Partial Least Square) version 3.0. The results of this study prove that directly transformational leadership, transactional leadership and Locus of Control significantly influence employee performance and indirectly Locus of Control does not moderate the influence of transformational leadership and transactional leadership on employee performance at Medan mayor's office.
\end{abstract}

Keywords: Transformational Leadership, Transactional Leadership, Locus of Control, Performance

\section{PENDAHULUAN}

Dalam melaksanakan kerjanya, pegawai menghasilkan sesuatu yang disebut dengan kinerja. Kinerja merupakan hasil kerja seseorang pegawai selama periode tertentu dibandingkan dengan berbagai kemungkinan misalnya standard, target/sasaran atau kriteria yang telah ditentukan terlebih dahulu dan disepakati bersama. Kinerja adalah hasil kerja yang dapat dicapai oleh seseorang atau sekelompok orang dalam suatu organisasi, sesuai dengan wewenang dan tanggung jawab masing-masing, dalam rangka upaya mencapai tujuan 
organisasi bersangkutan secara legal, tidak melanggar hukum dan sesuai dengan norma dan etika (Muis, Jufrizen, \& Fahmi, 2018).

Kinerja merupakan suatu hasil kerja yang dicapai seseorang dalam melaksanakan tugas-tugas yang dibebankan kepadanya yang didasarkan atas kecakapan, pengalaman dan kesungguhan serta waktu. Kinerja ini adalah gabungan dari tiga faktor penting yaitu kemampuan dan minat seseorang pekerja, kemampuan dan penerimaan atas penjelasan delegasi tugas dan peran serta tingkat motivasi seorang pekerja (Muis et al., 2018).

Selain itu kinerja disamakan dengan hasil kerja seorang pegawai. Untuk mencapai kinerja yang baik, unsur yang paling dominan adalah sumber daya manusia, walaupun perencanaan telah tersusun dengan baik dan rapi tetapi apabila orang atau personil yang melaksanakan tidak berkualitas dan tidak memiliki semangat kerja yang tinggi, maka perencanaan yang telah disusun tersebut akan sia-sia (Arianty, 2015).

Kepemimpinan merupakan faktor penting yang menentukan kinerja karyawan dan kemampuan organisasi beradaptasi dengan perubahan lingkungan. Kepemimpinan yang efektif harus memberikan pengarahan terhadap usaha-usaha semua pekerja dalam mencapai tujuan organisasi. Tanpa kepemimpinan, hubungan antara tujuan perseorangan dan tujuan organisasi mungkin menjadi tidak searah. Situasi ini akan menimbulkan keadaan dimana seorang karyawan dalam bekerja hanya untuk mencapai tujuan pribadinya, sementara itu keseluruhan organisasi menjadi tidak efisien dalam pencapaian tujuannya. Kepemimpinan merupakan suatu kemampuan yang melekat pada diri seorang yang memimpin yang tergantung dari macam-macam faktor baik faktor-faktor intern maupun faktor-faktor ekstern (Jufrizen, 2017).

Selain itu kepemimpinan merupakan salah satu faktor yang membentuk dan membantu orang lain untuk berkerja dan antusias mencapai tujuan yang direncanakan dalam kaitannya dengan keberhasilan organisasi mewujudkan tujuan sebagian besar ditentukan oleh kepemimpinan dan tingginya kinerja karyawan dalam melaksanakan tugas - tugasnya (Arianty, 2015).

Melihat pentingnya kepemimpinan terhadap kinerja maka diperlukan pimpinan pimpinan yang benar - benar dapat menjalankan fungsinya dengan tepat agar semua pihak yang ada didalam sebuah organisasi/perusahaan dapat menjalankan tugasnya dengan baik. Dalam kenyataannya para pemimpin dapat mempengaruhi moral dan kinerja, loyalitas kerja, keamanan, kualitas kehidupan kerja terutama tingkat kinerja suatu organisasi (Handoko \& Hanny, 2013). Kepemimpinan transformasional adalah merupakan proses dimana orang terlibat dengan orang lain, dan menciptakan hubungan yang yang menciptakan motivasi dan moralitas dalam diri pemimpin dan pengikut. Untuk memilah kompleksitas yang terkait dengan komponen peningkatan moral dari kepemimpinan transformasional murni (Nothouse, 2013).

Kepemimpinan transformasional adalah tipe kepemimpinan yang memadu atau memotivasi pengikut mereka dalam arah tujuan yang ditegakkan dengan memperjelas peran dan tuntutan tugas. Pemimpin jenis ini yang memberikan pertimbangan dan rangsangan intelektual yang diindividualkan, dan yang memiliki karisma. Pemimpin transformasional mencurahkan perhatian pada keprihatinan dan kebutuhan pengembangan dari pengikut individual; mereka mengubah kesadaran para pengikut akan persoalan- persoalan dengan membantu mereka memandang masalah dengan cara-cara baru; dan mereka mampu menggairahkan, membangkitkan, dan mengilhami para pengikut untuk mengeluarkan upaya ekstra untuk mencapai tujuan kelompok (Rivai, 2014).

Kepemimpinan transaksional dapat disebut sebagai kepemimpinan yang memberikan motivasi kepada para karyawan serta imbalan yang mereka dapatkan jika target yang ditentukan tercapai sehingga karyawan merasa terpacu untuk bekerja dengan lebih baik. Kepemimpinan transaksonal yaitu kepemimpinan yang mendapatkan motivasi para 
bawahannya dengan menyerukan ketertarikan mereka sendiri. Perilaku kepemimpinan terfokus pada hasil dari tugas dan hubungan dari pekerja yang baik dalam pertukaran untuk penghargaan yang diinginkan. Kepemimpinan transaksional mendorong pemimpin untuk menyesuaikan gaya dan perilaku mereka untuk memahami harapan pengikut (Thomas \& Velthouse, 2003).

Selain kepemimpinan kriteria kinerja yang baik menuntut karyawan untuk berperilaku sesuai harapan perusahaan, namun perusahaan juga harus memperhatikan aspek-aspek yang dapat membuat karyawan bertahan dan nyaman akan kondisi serta lingkungan kerjanya. Perusahaan yang menyadari pentingnya memelihara kinerja karyawan akan selalu memperhatikan faktor-faktor yang dapat meningkatkan semangat kerja karyawan. Peningkatan kinerja pegawai dalam pekerjaan pada dasarnya akan dipengaruhi oleh kondisi - kondisi tertentu, yaitu kondisi yang berasal dari luar individu yang disebut dengan faktor situasional meliputi kepemimpinan, prestasi kerja, hubungan sosial, lingkungan kerja, serta budaya organisasi. Sedangkan kondisi yang berasal dari dalam yang disebut dengan faktor individual meliputi jenis kelamin, kesehatan, pengalaman, dan karakteristik psikologis yang terdiri dari motivasi, kepribadian, dan locus of control (Falikhatun, 2003). Setiap individu memiliki keyakinan dan persepsi atas segala sesuatu yang mempengaruhi dirinya. Keyakinan inilah yang disebut locus of control. Locus of control merupakan generalized belief that a person can or cannot control his own destiny yaitu keyakinan bahwa seseorang dapat atau tidak dapat mengendalikan takdirnya sendiri (Ayudiati, 2010).

Kantor Walikota Medan merupakan kantor pemerintah kota Medan, berdasarkan peneliti menemukan fenomena yang terjadi di Kantor Walikota Medan yaitu yaitu masih rendahnya kinerja pegawai dalam melakukan pekerjaan dapat dilihat dari pegawai kurang mampu menyelesaikan pekerjaan tepat pada waktunya, hal ini di sebabkan oleh kurangnya pengarahan dari pemimpin dimana Pemimpin kurang memberikan contoh sikap dan perilaku yang baik kepada pegawai dan kurangannya pendekatan antara pemimpin kepada pegawai sehingga pegawai merasa kurang maksimal dalam bekerja, selain itu pemimpin kurang memberikan motivasi kepada para pegawai serta imbalan yang mereka dapatkan jika target yang ditentukan tercapai sehingga pegawai merasa tidak terpacu untuk bekerja dengan lebih baik. Kurangnya keyakinan dan persepsi yang dimilki pegawai atas segala sesuatu yang mempengaruhi dirinya dalam bekerja juga merupakan salah satu penyebab rendahnya kinerja pegawai Kantor Walikota Medan.

\section{KAJIAN LITERATUR \\ Kinerja}

Kinerja merupakan suatu hasil kerja yang dihasilkan oleh seorang karyawan diartikan untuk mencapai tujuan yang diharapkan. Selain itu kinerja seorang karyawan merupakan hal yang bersifat individual, karena setiap karyawan mempunyai tingkat kemampuan yang berbeda - beda dalam mengerjakan tugasnya. Pihak manajemen dapat mengukur karyawan atas hasil kerjanya berdasarkan kinerja dari masing - masing karyawan. Kinerja dan bukan merupakan hasil yang dapat dilihat pada saat itu juga.

Menurut (Mangkunegara, 2014) berpendapat bahwa kinerja karyawan adalah hasil kerja secara kualitas dan kuantitas yang dicapai oleh seseorang karyawan dalam melaksnakan tugasnya sesuai dengan tanggung jawab yang diberikan kepadanya. Menurut (Wibowo, 2010) menyatakan bahwa kinerja berasal darikata performance yang berarti hasil pekerjaan atau prestasi kerja. Namun perlu dipahami bahwa kinerja itu bukan sekedar hasil pekerjaan atau prestasi kerja, tetapi juga mencakup bagaimana proses pekerjaan itu berlangsung.

Menurut (Rivai, 2014) kinerja merupakan penampilan hasil kerja pegawai baik secara kuantitas maupun mutu. Sedangka menurut (Darmadi, 2018) menyatakan bahwa kinerja 
pegawai dapat merupakan penampilan individu maupun kelompok kerja pegawai. Tiga hal penting dalam kinerja pegawai adalah tujuan, ukuran, dan penilaian. Menurut (Susanto, 2017) menyebutkan bahwa kinerja pegawai (performance)adalah hasil kerja yang dapat dicapai oleh seseorang atau sekelompok orang dalam suatu organisasi, sesuai dengan wewenang dan tanggung jawab masing-masing, dalam rangka upaya mencapai tujuan organisasi bersangkutan secara legal, tidak melanggar hukum dan sesuai dengan moral maupun etika. Menurut (Robbins, 2012) kinerja merupakan pengukuran terhadap hasil kerja yang diharapkan berupa sesuatu yang optimal. Faktor-Faktor yang mempengarui kinerja adalah: iklim organisasi, kepemimpinan, kualitas pekerjaan, kemampuan kerja, inisiatif, motivasi, daya tahan/ kehandalan, kuantitas pekerjaan, disiplin kerja dan pengawasan.

Menurut (Wibowo, 2010) mengemukakan bahwa faktor-faktor yang mempengaruhi kinerja adalah sebagai berikut : 1) Personal factor, ditunjukkan oleh tingkat keterampilan, kompetensi yangdimiliki, motivasi dan komitmen individu, 2) Leadership factor, ditentukan oleh kualitas dorongan, bimbingan dan dukungan yang dilakukan manajer dan team leader, 3). Team factor, ditunjukkan oleh kualitas dukungan yang diberikan oleh rekan sekerjanya, 4). System factor, ditunjukkan oleh adanya sistem kerja dan fasilitas yang diberikan organisasi, 5). Contextual/situation factor, ditunjukkan oleh tingginya tingkat tekanan dan perubahan lingkungan internal dan eksternal, dan 6). Aturan-aturan prilaku yaitu para partisipan organisasi saling berinteraksi satu dengan yang lain, maka mereka menggunakan bahasa, terminology dan ritual-ritual yang sama berhubungan dengan rasahormat dan cara bertindak. Menurut (Mangkunegara, 2014) faktor yang mempengaruhi pencapaian kinerja adalah faktor kemampuan (ability) dan faktor motivasi (motivation). Menurut (Sutrisno, 2010) faktor-faktor yang mempengaruhi kinerja seorang karyawan adalah efektivitas dan efisiensi, otoritas dan tanggung jawab, disiplin dan inisiatif. Indikator kinerja merupakan sesuatu yang akan dihitung dan diukur. Adapun indikator kinerja (Mangkunegara, 2014) menyatakan yaitu: kualitas kerja, kuantitas kerja, dapat tidaknya diandalkan dan sikap. sedangkan menurut (Sutrisno, 2010) mengemukakan secara umum dapat dinyatakan bahwa terdapat 3 aspek indikator kinerja, yaitu kualitas, kuantitas dan waktu kerja.

\section{Kepemimpinan Tranformasional}

Menurut (Nothouse, 2013) kepemimpinan transformasional adalah Kepemimpinan transformasional yang murni adalah kepemimpinan yang bersifat sosial dan peduli dengan kebaikan bersama. Pemimpin transformasional yang bersifat sosial ini mengalahkan kepentingan mereka sendiri demi kebaikan orang lain. Selanjutnya (Rivai, 2014) menyatakan bahwa kepemimpinan transformasional adalah tipe kepemimpinan yang memadu atau memotivasi pengikut mereka dalam arah tujuan yang ditegakkan dengan memperjelas peran dan tuntutan tugas.pemimpin jenis ini yang memberikan pertimbangan dan rangsangan intelektual yang diindividualkan, dan yang memiliki karisma. Pemimpin transformasional mencurahkan perhatian pada keprihatinan dan kebutuhan pengembangan dari pengikut individual; mereka mengubah kesadaran para pengikut akan persoalan- persoalan dengan membantu mereka memandang masalah dengan cara-cara baru dan mereka mampu menggairahkan, membangkitkan, dan mengilhami para pengikut untuk mengeluarkan upaya ekstra untuk mencapai tujuan kelompok.

Menurut (Bryman, 2012) menyatakan bahwa kepemimpinan transformasional adalah bagian dari paradigma kepemimpinan baru yang lebih memberikan perhatian pada elemen kepemimpinan yang karismatik dan peka. Menurut (Yukl, 2010) menyatakan bahwa menyatakan bahwa kepemimpinan transformasional sebagai suatu proses dimana pemimpin dan pengikutnya bersama-sama saling meningkatkan dan mengembangkan moralitas dan 
motivasinya. Pemimpin yang menerapkan gaya kepemimpinan transformasional menjadikan pengikutnya melihat bahwa tujuan yang mau dicapai lebih dari sekedar kepentingan pribadinya. Gray Yukl pada konteks ini menekankan bahwa pemimpin transformasional akan melakukan banyak hal untuk memberdayakan pengikutnya dan menjadikan mereka untuk tidak lagi bergantung kepada dirinya, seperti mendelegasikan otoritas terhadap tiap individu, mengembangkan keterampilan dan kepercayaan diri pengikutnya, menciptakan swakclola, meminimalisir hal yang tidak perlu dikontrol, dan membangun dudaya yang kuat untuk pemberdayaan pengikutnya (Wahab \& Umiarso, 2011).

Kepemimpinan transformasional peduli dengan perbaikan kinerja pengikut, dan mengembangkan pengikut ke potensi maksimal mereka. Orang yang menampilkan kepemimpinan transformasional sering kali memiliki kumpulan nilai serta prinsip internal yang kuat. Mereka efektif dalam memotivasi pengikut untuk bertindak dalam cara yang mendukung kepentingan yang lebih besar, dari pada kepentingan meraka sendiri (Nothouse, 2013). Ada empat faktor gaya kepemimpinan transformasional yang dipengaruhi yaitu:

1) Pengaruh ideal adalah komponen emosional dari kepemimpinan. Pengaruh ideal mendeskripsikan pemimpin yang bertindak sebaga teladan yang kuat sebagai pengikut.

2) Motivasi yang menginspirasi Faktor ini menggambarkan pemimpin yang mengomunikasikan harapan tinggi kepada karyawan, menginspirasi mereka lewat motivasi untuk menjadi setia pada dan menjadi bagian dari visi bersama dalam organisasi.

3) Rangsangan intelektual Hak ini mencakup yang merangsang pengikut untuk bersikap kreatif dan inovatif serta merangsang keyakinan dan nilai mereka sendiri, seperti juga nilai dan keyakinan pemimpin serta organisasi.

4) Pertimbangan yang diadaptasi Faktor ini mewakili pemimpin yang memberikan iklim yang mendukung, dimana mereka mendengarkan dengan saksama kebutuhan masing-masing pengikut. Pemimpin bertindak sebagai pelatih dan penasihat, sambil mencoba untuk membantu karyawan bener-benar mewujudkan apa yang diinginkan.

Agar gaya kepemimpinan manajer berubah ke gaya yang lebih sesuai dengan situasi, maka persepsi manajer mengenai situasi tersebut pertamatama harus diubah (Achmad, 2016). Faktor-faktor yang mempengaruhi efektivitas kepemimpinan mencakup yaitu: Kepribadian, pengalaman masa lampau, dan harapan dari pemimpin yang bersangkutan, harapan dan perilaku atasan, karakteristik, harapan, perilaku bawahan, persyaratan tugas, kultur dan kebijakan organisasi dan harapan serta perilaku rekan kerja.

Menurut (Kartini, 2010) mengungkapkan bahwa kepemimpinan transformasional memiliki empat indikator yaitu :

1) Karisma (Charisma), memberikan visi dan misi, menanamkan rasa bangga, mendapatkan perhatian (respec) dan kepercayaan (trust). Pemimpin transformasional terlihat karismatik oleh pengikutnya dan mempunyai suatu kekuatan dan pengaruh.

2) Inspirasional (Inspirasioni), mengkomunikasikan ekspektasi yang tinggi, menggunakan simbul untuk memfokuskan upaya, mengekspresikan tujuan dengan cara-cara yang sederhana.

3) Stimulasi Intelektual (Intelektual Stimulation), menghargai ide-ide bawahan (promote intelegence), mengembangkan rasionalisasi dan melakukan pemecahan masalah secara cermat.

4) Perhatian Individu (Individualized Consideration), memberikan perhatian pada pribadi, menghargai perbedaan setiap individual, memberi nasehat dan pengarahan.

\section{Kepemimpinan Transaksional}

Kepemimpinan transaksional adalah pemimpin yang memotivasi para karyawan melalui imbalan dan dikerjakan oleh karyawan agar mereka dapat mencapai tujuan mereka 
sendiri atau organisasi dan membantu karyawan agar memperoleh kepercayaan dalam mengerjakan pekerjaannya. Menurut (Siagian, 2014) mengatakan bahwa kepemimpinan transaksional yaitu pemimpin yang memberikan sebuah pertukaran melalui imbalan-imbalan untuk mendapatkan kepatuhan atas apa yang telah mereka lakukan. Selanjutnya menurut (Bass \& Riggio, 2006) menyatakan bahwa kepemimpinan transaksional merupakan sebuah kepemimpinan dimana seorang pemimpin mendorong para karyawan atau bawahannya untuk bekerja dengan menyediakan sumberdaya dan penghargaan sebagai imbalan untuk motivasi, produktivitas dan pencapaian tugas yang efektif.

Sedangkan menurut (Thomas \& Velthouse, 2003) menyatakan bahwa kepemimpinan transaksonal yaitu kepemimpinan yang mendapatkan motivasi para bawahannya dengan menyerukan ketertarikan mereka sendiri. Perilaku kepemimpinan terfokus pada hasil dari tugas dan hubungan dari pekerja yang baik dalam pertukaran untuk penghargaan yang diinginkan. Kepemimpinan transaksional mendorong pemimpin untuk menyesuaikan gaya dan perilaku mereka untuk memahami harapan pengikut.

Pemberian motivasi kepada karyawan merupakan kewajiban para pimpinan, agar para karyawan tersebut dapat lebih meningkatkan volume dan mutu pekerjaan yang menjadi tanggung jawab. Untuk itu, menurut (Rivai, 2014) seorang pemimpin harus memperhatikan hal-hal berikut agar pemberian motivasi dapat berhasil seperti yang diharapkan, yaitu: 1) Memahami perilaku bawahan dan harus dapat memberi teladan, 2). Harus berbakat dan berperilaku realistis, 3). Tingkat kebutuhan setiap orang berbeda, 4). Mampu menggunakan keahlian, dan 5). Pemberian motivasi harus mengacu pada orang.

Selanjutnya (Setiawan \& Muhith, 2013) mengatakan bahwa faktor yang memengaruhi gaya kepemimpinan adalah 1). Kepribadian (personality), pengalaman masa lalu dan harapan pemimpin, hal ini mencakup nilai-nilai, latar belakang dan pengalamannya akan memengaruhi pilihan akan gaya kepemimpinan, 2) Harapan dan perilaku atasan, 3) Karakteristik, harapan dan perilaku bawahan memengaruhi terhadap apa gaya kepemimpinan, 4). Kebutuhan tugas, setiap tugas bawahan juga akan memengaruhi gaya pemimpin, 5). Iklim dan kebijakan organisasi memengaruhi harapan dan perilaku bawahan, dan 6). Harapan dan perilaku rekan. Menurut (Yukl, 2010) indikator - indikator yang mempengaruh Kepemimpinan Transaksional yaitu : 1) Imbalan Kontingen (Contingent Reward), 2). Manajemen Eksepsi Aktif (Active Management by Exception), 3). Manajemen Eksepsi Pasif (Passive Management By Exception). Menurut (Robbins, 2012) indikator dari kepemimpinan Transaksional adalah Imbalan Kontinjen (Contingensi Reward), Manajemen dengan pengecualian / eksepsi aktif (Active Management by Exception ), dan Manajemen dengan pengecualian / eksepsi pasif (Pasive Management by Exception)

\section{Locus Of Control}

Locus of control menurut (Rotter, 2009) adalah suatu hal yang dipastikan memberikan kontribusi terhadap kualitas kinerja pada seseorang, yaitu respon awal sebagai dasar dari respon yang akan dilakukan selanjutnya. Locus of control menurut (Munir \& Mehsoon, 2010) adalah cerminan dari sebuah kecendrungan seorang individu untuk percaya bahwa dia mengendalikan peristiwa yang terjadi dalam hidupnya (internal) atau kendali atas peristiwa yang terjadi dalam hidupnya itu berasal dari hal lain, misalnya kuasa orang lain (eksternal). Locus of control menurut (Kutanis, Mesci, \& Ovdur, 2011) mencakup gagasan bahwa individu sepanjang hidup mereka, menganalisis peristiwa sebagai hasil dari perilaku mereka atau mereka percaya bahwa peristiwa tersebut merupakan hasil dari kebetulan, nasib atau kekuatan di luar kendali mereka. Locus of control menurut (April, Dharani, \& Peters, 2012) digambarkan sebagai dimensi dengan dua sisi yang berlawanan. Dimensi yang mencerminkan sejauh mana orang percaya 
bahwa apa yang terjadi kepada mereka adalah dalam kendali mereka atau di luar kendali mereka

Locus of control menurut (Robbins, 2012) adalah tingkat di mana individu yakin bahwa mereka adalah penentu nasib mereka sendiri. Faktor internal adalah individu yang yakin bahwa mereka merupakan pemegang kendali atas apaapa pun yang terjadi pada diri mereka, sedangkan faktor eksternal adalah individu yang yakin bahwa apapun yang terjadi pada diri mereka dikendalikan oleh kekuatan luar seperti keberuntungan dan kesempatan.

Faktor-faktor yang mempengaruhi locus of control seorang individu menurut (Hamedoglu, Kantor, \& Gulay, 2012) yaitu: 1) Faktor keluarga, 2) Faktor motivasi, dan 3) Faktor pelatihan. Sedangkan (Crider, 1983) menyatakan bahwa perbedaan karakteristik antara locus of control internal dan eksternal adalah sebagai berikut:

1) Locus of control internal

a) Suka bekerja keras.

b) Memiliki insiatif yang tinggi.

c) Selalu berusaha untuk menemukan pemecahan masalah.

d) Selalu mencoba untuk berfikir seefektif mungkin.

e) Selalu mempunyai persepsi bahwa usaha harus dilakukan jika ingin berhasil.

2) Locus of control external

a) Kurang memiliki inisiatif.

b) Mudah menyerah, kurang suka berusaha karena mereka percaya bahwa faktor luarlah yang mengontrol.

c) Kurang mencari informasi.

d) Mempunyai harapan bahwa ada sedikit korelasi antara usaha dan kesuksesan.

e) Lebih mudah dipengaruhi dan tergantung pada petunjuk orang lain.

Menurut (Azwar, 2004) locus of control terdiri dari tiga indikator yaitu internality, chance dan powerful others.

1) Internality Internality adalah keyakinan seseorang bahwa kejadian-kejadian dalam hidupnya ditentukan terutama oleh kemampuan dirinya sendiri seperti keterampilan dan potensi-potensi yang dimilikinya.

2) Chance Chance adalah keyakinan seseorang bahwa kejadian-kejadian dalam hidupnya ditentukan terutama oleh nasib, peluang dan keberuntungan.

3) Powerful others Powerful others adalah keyakinan seseorang bahwa kejadian-kejadian dalam hidupnya ditentukan terutama oleh orang lain yang lebih berkuasa.

\section{Kerangka Konseptual}

\section{Pengaruh Kepemimpinan Transformasional Terhadap Kinerja}

Kepemimpinan menunjukkan bahwa proses ini melibatkan kemampuan individu untuk memotivasi dan mempengaruhi orang lain, sementara definisi dasar kepemimpinan secara konsisten telah digunakan sebagai dasar untuk mengevaluasi kepemimpinan, para ahli telah mengembangkan dasar-dasar teori kepemimpinan dalam praktek seperti Sifat, perilaku, situasional, transaksional dan transformasi (Orabi \& Tareq, 2016).

Menurut (Nothouse, 2013) kepemimpinan transformasional adalah Kepemimpinan transformasional yang murni adalah kepemimpinan yang bersifat sosial dan peduli dengan kebaikan bersama. Pemimpin transformasional yang bersifat sosial ini mengalahkan kepentingan mereka sendiri demi kebaikan orang lain. Hasil penelitian hasil terdahulu yang dilakukan oleh (Cahyono, Maarif, \& Suharjono, 2014), (Tucunan, Suprtha, \& Riana, 2014), (Amri, Suharmono, \& Rahardja, 2016), (Nasution, 2018) dan (Jufrizen, 2017) membuktikan 
bahwa Kepemimpinan Transformasional memiliki pengaruh yang signifikan terhadap kinerja karyawan.

\section{Pengaruh Kepemimpinan Transaksional Terhadap Kinerja}

Pola hubungan yang dikembangkan kepemimpinan transaksional adalah berdasarkan suatu sistem timbal balik (transaksi) yang sangat menguntungkan (mutual system of reinforcement) yaitu pemimpin memahami kebutuhan dasar para pengikutnya dan pemimpin menemukan penyelesaian atas cara kerja dari para pengikutnya tersebut. Pemimpin transaksional merancang cara kerja sedemikian rupa yang disesuaikan dengan jenis dan jenjang jabatannya dan melakukan interaksi atau hubungan mutualis. Kepemimpinan Transaksional yang diterapkan oleh seorang pimpinan akan mendorong karyawannya bekerja lebih baik lagi, sehingga program atau sasaran yang telah ditetapkan oleh organisasi akan dapat dicapai. Kinerja karyawan pada dasarnya merupakan ukuran kesuksesan perhitungan hasil akhir atau tingkat pencapaian hasil, baik oleh individu maupun kelompok dalam suatu organisasi untuk mencapai tujuan yang telah ditentukan.

Menurut (Siagian, 2014) mengatakan bahwa kepemimpinan transaksional yaitu pemimpin yang memberikan sebuah pertukaran melalui imbalan-imbalan untuk mendapatkan kepatuhan atas apa yang telah mereka lakukan. Hasil penelitian yang dilakukan oleh (Oktora, Rizan, \& Situngkir, 2018) dan (Anggini, Musadieq, \& Sulistyo, 2018) menyimpulkan bahwa Kepemimpinan Transaksional berpengaruh terhadap kinerja.

\section{Pengaruh Kepemimpinan Transformasional dan Kepemimpinan Transaksional Terhadap Kinerja}

Berhasil atau tidaknya sebuah perusahaan sangat ditentukan oleh kepemimpinan, karena pemimpin bertanggungjawab atas kegagalan pelaksanaan pekerjaan, sebaliknya kesuksesan dalam memimpin sebuah organisasi merupakan keberhasilan seseorang mempengaruhi orang lain untuk menggerakkan atau menjalankan visinya, selain itu adanya koordinasi atau kerjasama yang baik antara pimpinan dan bawahannya. Kepemimpinan mempunyai kaitan yang erat dengan motivasi karena keberhasilan seorang pemimpin dalam menggerakkan orang lain dalam mencapai tujuan yang telah ditetapkan sangat bergantung kepada kewibawaan, selain itu bagaimana menciptakan motivasi dalam diri setiap karyawan, kolega ataupun pimpinan itu sendiri.

Gaya kepemimpinan transformasional merupakan kepemimpinan yang terkait dengan identifikasi diri yang kuat, penciptaan visi bersama untuk masa depan dan hubungan antara pemimpin dan pengikut berdasar pada suatu hal yang lebih daripada sekedar pemberian penghargaan agar patuh. Pemimpin transformasional mendefinisikan kebutuhan untuk perubahan, menciptakan visi baru, memobilisasi komitmen untuk menjalankan visi dan mentransformasi pengikut baik pada tingkat individual maupun tingkat organisasi.

Kepemimpinan Transaksional yang diterapkan oleh seorang pimpinan akan mendorong karyawannya bekerja lebih baik lagi, sehingga program atau sasaran yang telah ditetapkan oleh organisasi akan dapat dicapai. Kinerja karyawan pada dasarnya merupakan ukuran kesuksesan perhitungan hasil akhir atau tingkat pencapaian hasil, baik oleh individu maupun kelompok dalam suatu organisasi untuk mencapai tujuan yang telah ditentukan

Hasil penelitian yang dilakukan oleh (Oktora et al., 2018) menyimpulkan bahwa gaya kepemimpinan transformasional, Kepemimpinan Transaksional, motivasi serta kompetensi berpengaruh secara bersama-sama terhadap kinerja. Sedangkan menurut hasi penelitian terdahulu yang dilakukan oleh (Arianty, 2015) menyimpulkan bahwa kepemimpinan berpengaruh terhadap kinerja. 


\section{Locus Of Control Moderasi Pengaruh Kepemimpinan Transformasional dan Kepemimpinan Transaksional Terhadap Kinerja}

Kinerja yang baik merupakan keinginan bagi setiap perusahaan, akan tetapi selalu saja ada faktor lain yang menjadi penyebab terjadinya kenaikan dan penurunan kinerja dalam suatu perusahaan,

Menurut (Mangkunegara, 2014) berpendapat bahwa kinerja karyawan adalah hasil kerja secara kualitas dan kuantitas yang dicapai oleh seseorang karyawan dalam melaksnakan tugasnya sesuai dengan tanggung jawab yang diberikan kepadanya.

Gaya kepemimpinan transformasional merupakan kepemimpinan yang terkait dengan identifikasi diri yang kuat, penciptaan visi bersama untuk masa depan dan hubungan antara pemimpin dan pengikut berdasar pada suatu hal yang lebih daripada sekedar pemberian penghargaan agar patuh. Pemimpin transformasional mendefinisikan kebutuhan untuk perubahan, menciptakan visi baru, memobilisasi komitmen untuk menjalankan visi dan mentransformasi pengikut baik pada tingkat individual maupun tingkat organisasi.

Kepemimpinan Transaksional yang diterapkan oleh seorang pimpinan akan mendorong karyawannya bekerja lebih baik lagi, sehingga program atau sasaran yang telah ditetapkan oleh organisasi akan dapat dicapai. Kinerja karyawan pada dasarnya merupakan ukuran kesuksesan perhitungan hasil akhir atau tingkat pencapaian hasil, baik oleh individu maupun kelompok dalam suatu organisasi untuk mencapai tujuan yang telah ditentukan

Locus of control menurut Demirtas \& Güneş, (2012) dapat didefinisikan adalah sebagai kekuatan yang mengendalikan tindakan diri karyawan dan hal-hal yang dilakukan terhadap mereka, selain itu locus of control dianggap sebagai persepsi orang tentang siapa atau apa yang bertanggung jawab atas hasil dari perilaku atau peristiwa dalam kehidupan mereka.

Berdasarkan uraian sebelumnya dan penelitian terdahulu maka kerangka konseptual dalam penelitian ini adalah sebagai berikut :

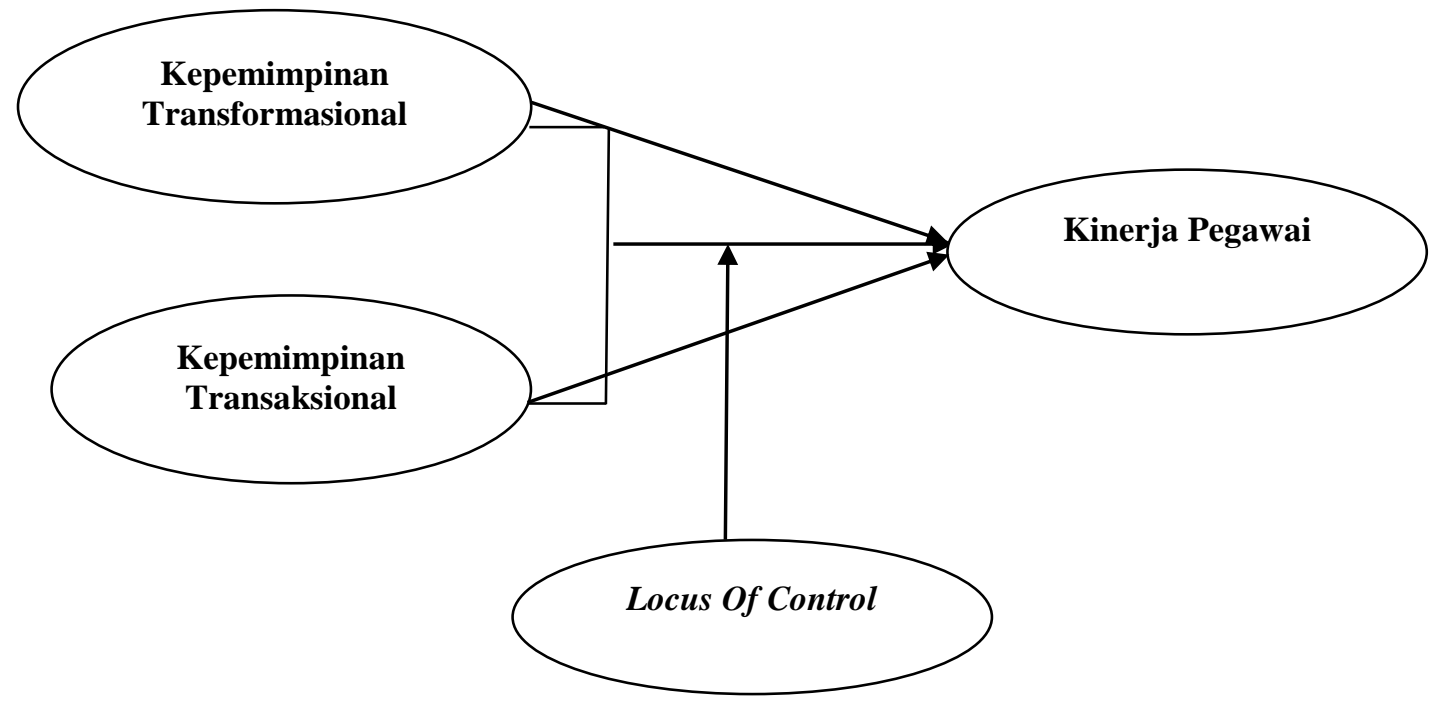

Gambar 1. Kerangka Konseptual

\section{METODE PENELITIAN}

Penelitian ini menggunakan pendekatan penelitian eksplanatori, yang bertujuan untuk menjelaskan hubungan sebab akibat antara variabel penelitian dan hipotesis pengujian (Muhammad Irfan Nasution, Fahmi, Jufrizen, Muslih, \& Prayogi, 2020). Dalam penelitian ini menggunakan jenis pendekatan assosiatif dan kuantitatif. Populasi dalam penelitian ini adalah 
seluruh pegawai yang terdapat pada Kantor Walikota Medan yang berjumlah 89. Adapun Untuk penentuan jumlah/ukuran sampel dalam penelitian ini dengan metode sampel jenuh dimana semua anggota populasi dijadikan sampel yaitu sebanyak 89 orang.

Sebelum dilakukan pengumpulan data, terlebih dahulu untuk menentukan cara pengumpulan data apa yang akan digunakan digunakan. Alat pegumpulan data yang digunakan harus sesuai dengan kesahihan (validitas) dan keandalan atau konsistensi (realibilitas). Menurut (Juliandi et al., 2015) ada 3 alat pengumpulan data yang akan digunakan oleh peneliti adalah wawancara/Interview dan Kuisioner/angket. Data ini akan dianalisis dengan pendekatan kuantitatif menggunakan analisis statistik yakni partial least square - structural equestion model (PLS-SEM) yang bertujuan untuk melakukan analisis jalur (path) dengan variabel laten. Analisis ini sering disebut sebagai generasi kedua dari analisis multivariate (Ghozali, 2016) Analisis persamaan struktural (SEM) berbasis varian yang secara simultan dapat melakukan pengujian model pengukuran sekaligus pengujian model struktural. Model pengukuran digunakan untuk uji validitas dan reliabilitas, sedangkan model struktural digunakan untuk uji kausalitas (pengujian hipotesis dengan model prediksi)

\section{HASIL DAN PEMBAHASAN \\ Hasil Penelitian}

Dalam penelitian ini penulis mengola data angket dalam bentuk data yang terdiri dari 8 pernyataan untuk variabel kepemimpinan transformasional (X1), 6 pernyataan untuk variabel kepemimpinan transaksional (X2), 6 pernyataan untuk variabel Locus Of Control (Z) dan 8 pernyataan untuk variabel linerja pegawai (Y). Angket yang disebarkan ini diberikan kepada 89 orang pegawai Kantor Walikota Medan sebagai responden pada sampel penelitian dengan menggunakan skala likert berbentuk tabel cheklist.

\section{Persyaratan Analisis}

Analisis data dalam penelitian ini menggunakan Structural Equation Model Partial Least Square (SEM-PLS). Sebagai alternaitf covariance based SEM, pendekatan variance based atau component based dengan PLS berorientasi analisis bergeser dari menguji model kausalitas/teori ke component based predictive model. Pengujian model struktural dalam PLS dilakukan dengan bantuan software Smart PLS ver. 3 for Windows. Berikut adalah hasil model struktural yang dibentuk dari perumusan masalah:

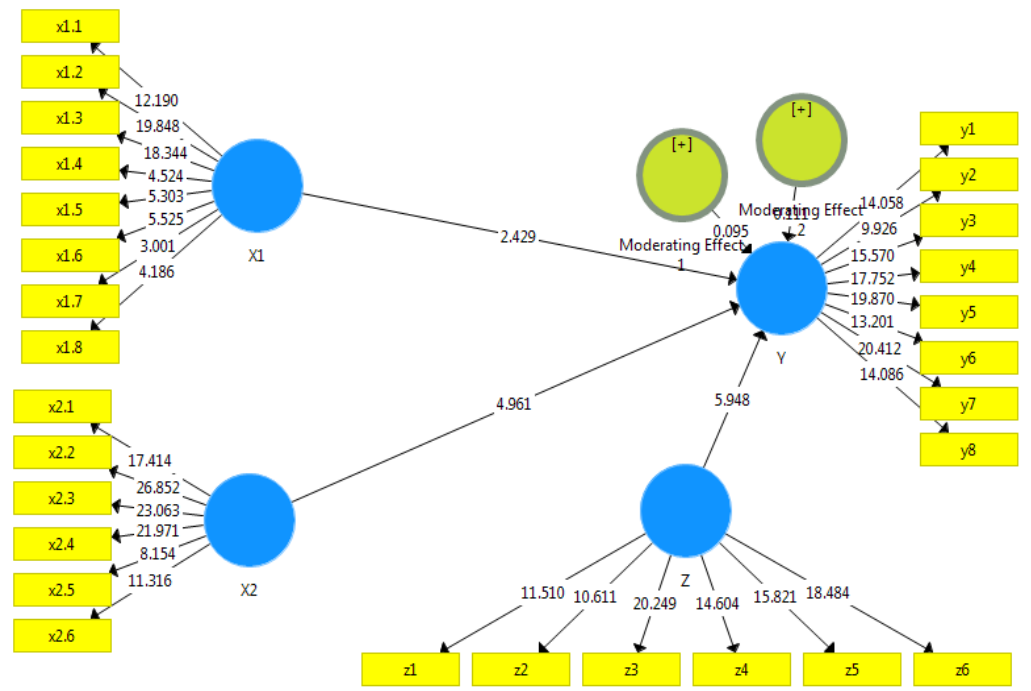

Gambar 2. Hasil Model Struktural PLS 
Ada dua tahapan kelompok untuk menganalisis SEM-PLS yaitu analisis model pengukuran (outer model), yakni (a) validitas konvergen (convergent validity); (b) realibilitas dan validitas konstruk (construct reliability and validity); dan (c) validitas diskriminan (discriminant validity) serta analisis model struktural (inner model), yakni (a) koefisien determinasi (r-square); (b) f-square; dan (c) pengujian hipotesis (Hair, Hult, Ringle, \& Sarstedt, 2014).

\section{Analisis Partial Least Square}

\section{Analisis Model Pengukuran/Measurement Model Analysis (Outer Model)}

Analisis model pengukuran/measurement model analysis (outer model) menggunakan 2 pengujian, antara lain: (1) Construct reliability and validity dan (2) Discriminant validity berikut ini hasil pengujiannya.

\section{a. Construct reliability and validity}

Validitas dan reliabilitas konstruk adalah pengujian untuk mengukur kehandalan suantu konstruk. Kehandalan skor konstruk harus cukup tinggi. Kriteria composite reliability adalah > 0.6 (Juliandi, 2018)

Tabel 1. Composite Reliability

\begin{tabular}{cc}
\hline & Composite Reliability \\
\hline $\mathrm{X} 1$ & 0,888 \\
\hline $\mathrm{X} 2$ & 0,931 \\
\hline $\mathrm{Y}$ & 0,943 \\
\hline $\mathrm{Z}$ & 0,917 \\
\hline
\end{tabular}

Sumber : Data SEM-PLS 2020

Kesimpulan pengujian composite reliability adalah sebagai berikut :

1) Variabel kepemimpinan transformasional (X1) adalah reliable, karena nilai composite reliability transformasional $(\mathrm{X} 1)$ adalah $0.888>0.6$

2) Variabel kepemimpinan transaksinal (X2) adalah reliable, karena nilai composite reliability kepemimpinan transaksioanl (X2) adalah $0.931>0.6$

3) Variabel locus of control (Z) adalah reliable, karena nilai composite reliability locus of control $(\mathrm{Z})$ adalah $0.917>0.6$

4) Variabel kinerja (Y) adalah reliable, karena nilai composite reliability kinerja (Y) adalah $0.943>0.6$.

\section{b. Discriminant Validity}

Discriminant validity adalah sejauh mana suatu konstruk benar-benar berbeda dari konstruksi lain (konstruk adalah unik). Kriteria pengukuran terbaru yang terbaik adalah melihat nilai Heretroit-Monotrait Ratio (HTMT). Jika nilai HTMT $<0.90$ maka suatu konstruk memiliki validitas diskriminan yang baik (Juliandi, 2018).

Tabel 2. Heretroit-Monotoroit Ratio (HTMT)

\begin{tabular}{ccccc} 
& \multicolumn{4}{c}{ Heretroit-Monotoroit Ratio (HTMT) } \\
\cline { 2 - 4 } & $\mathrm{X}$ & $\mathrm{X} 2$ & $\mathrm{Z}$ \\
\hline $\mathrm{X} 1$ & \multicolumn{4}{l}{} \\
\hline $\mathrm{X} 2$ & 0,837 & 1,016 & \\
\hline $\mathrm{Y}$ & 0,852 & 1,016 & 1,039 \\
\hline $\mathrm{Z}$ & 0,815 & &
\end{tabular}

Sumber : Data SEM-PLS 2020

Kesimpulan pengujian Heretroit-Monotrait Ratio(HTMT) adalah sebagai berikut : (1) Variabel X1 (kepemimpinan transformasional) terhadap X2 (kepemimpinan transaksional) 
memiliki Heretroit-Monotrait Ratio 0.0,837<0.90, artinya validitas discriminant baik, atau benar-benar berbeda dari konstruksi lain (konstruk adalah unik); (2) Variabel X1 (kepemimpinan transgormasional) terhadap Y (kinerja) nilai Heretroit Monotrait Ratio $0.852<0.90$, artinya validitas discriminant baik, atau benar-benar berbeda dari konstruksi lain (konstruk adalah unik); (3) variabel X2 (kepemimpinan transaksional) terhadap Y (kinerja) Heretroit Monotrait Ratio 1,016>0.90, artinya validitas discriminant kurang baik atau benar-benar berbeda dari konstruksi lain (konstruk adalah unik); (4) Variabel X1 (lepemimpinan transformasional) terhadap Z (locus of control) memiliki Heretroit Monotait Ratio $0.815<0.90$, artinya validitas discriminant baik ata benar-benar berbeda dari konstrulsi lain; (5) Variabel X2 (kepemimpinan transaksional) terhadap Z (lovus of control) memiliki Heretroit Monotrait Ratio 1,016>0.90, artinya validitas discriminant kurang baik, atau benar-benar berbeda dari kontruksi lain; (6) Variabel Y (kinerja) terhadap Z (Locus Of Control) nilai Heretroit Monotroit Ratio 1.039>0.90, artinya validitas discriminant lurang baik, atau benar-benar berbeda dari konstruksi lain(konstruk adalah unik).

\section{Analisis Model Struktural (Inner Model)}

Analisis model struktural bertujuan untuk menganalisis hipotesis penelitian. Minimal ada dua bagian yang perlu di analisis didalam model ini, yaitu: koefisien determinasi dan pengujian hipotesis.

\section{a. Koefisien determinasi (R-square)}

$\mathrm{R}$-square adalah ukuran proporsi variasi nilai yang dipengaruhi (endogen) yang dapat dijelaskan oleh variabel yang mempengaruhinya (eksogen) ini berguna untuk memprediksi apakah model adalah baik/buruk. Hasil r-square untuk variabel laten endogen sebesar 0,75 mengindikasikan bahwa model tersebut adalah substansial (baik); 0,50 mengindikasikan bahwa model tersebut adalah moderat (sedang) dan 0,25 mengindikasikan bahwa model tersebut adalah lemah (buruk).

Tabel 3. Hasil Uji R-Square

\begin{tabular}{llllrr}
\hline & $\begin{array}{l}\text { Original } \\
\text { Sample (O) }\end{array}$ & $\begin{array}{l}\text { Sample } \\
\text { Mean (M) }\end{array}$ & $\begin{array}{l}\text { Standard } \\
\text { Error } \\
\text { (STERR) }\end{array}$ & $\begin{array}{l}\text { T Statistics } \\
(\mid \text { O/STERR } \mid)\end{array}$ & P Values \\
\hline Y & 0,943 & 0,946 & 0,014 & 65,536 & 0,000 \\
\hline
\end{tabular}

\section{Sumber : PLS 3.00}

Dari tabel 3 di atas diketahui bahwa pengaruh X1, X2 dan $\mathrm{Z}$ terhadap $\mathrm{Y}$ dengan nilai r-square 0,943 mengindikasikan bahwa variasi nilai Y mampu dijelaskan oleh variasi nilai X1, $\mathrm{X} 2$ dan $\mathrm{Z}$ sebesar 94,3\% atau dengan kata lain bahwa model tersebut adalah substansial (baik), dan $5,7 \%$ dipengaruhi oleh variabel lain. Nilai probabilitas ( $p$-values) yang didapat adalah $0,000<0,05$ (signifikan), dengan demikian model tergolong lemah.

\section{b. F-Square}

F-square adalah ukuran yang digunakan untuk menilai dampak relatif dari suatu variabel yang mempengaruhi (eksogen) terhadap variabel yang dipengaruhi (endogen). Kriteria penarikan kesimpulan adalah jika nilai f2 sebesar 0,02 maka terdapat efek yang kecil (lemah) dari variabel eksogen terhadap endogen, nilai $\mathrm{f} 2$ sebesar 0,15 maka terdapat efek yang moderat dari variabel eksogen terhadap endogen, nilai f2 sebesar 0,35 maka terdapat efek yang besar dari variabel eksogem terhadap endogen. 
Tabel 4. Hasil Uji F-Square

\begin{tabular}{lccccc} 
& $\begin{array}{c}\text { Original } \\
\text { Sample (O) }\end{array}$ & $\begin{array}{c}\text { Sample } \\
\text { Mean (M) }\end{array}$ & $\begin{array}{c}\text { Standard } \\
\text { Error } \\
(\text { STERR) }\end{array}$ & $\begin{array}{c}\text { T Statistics } \\
(\text { (O/STERR) }\end{array}$ & P Values \\
\hline $\begin{array}{l}\text { Moderating } \\
\text { Effect 1 -> Y }\end{array}$ & 0,000 & 0,020 & 0,037 & 0,010 & 0,992 \\
\hline $\begin{array}{l}\text { Moderating } \\
\text { Effect 2 -> Y }\end{array}$ & 0,000 & 0,020 & 0,035 & 0,014 & 0,989 \\
\hline $\mathbf{X 1}$-> Y & 0,149 & 0,203 & 0,165 & 0,903 & 0,367 \\
\hline $\mathbf{X 2}$-> Y & 0,282 & 0,316 & 0,144 & 1,954 & 0,051 \\
\hline $\mathbf{Z}$-> Y & 0,449 & 0,480 & 0,165 & 2,721 & 0,007 \\
\hline
\end{tabular}

\section{Sumber : PLS 3.00}

Berdasarkan tabel 4 di atas diketahui bahwa: 1) Pengaruh kepemimipinan tranformasional terhadap kinerja pegawai sebesar 0,149 mengindikasi bahwa terdapat efek yang moderat (sedang), 2). Pengaruh kepemimipinan transaksional terhadap kinerja pegawai sebesar 0,282 mengindikasi bahwa terdapat efek yang moderat (sedang). 3). Pengaruh Locus Of Control terhadap kinerja pegawai sebesar 0,449 mengindikasi bahwa terdapat efek yang moderat (sedang). 4) Pengaruh kepemimpinan transformasional terhadap kinerja pegawai yang dimoderasi oleh Locus Od Control mempunyai koefisien jalur sebesar 0,000 mengindikasi bahwa terdapat efek yang lemah. 5). Pengaruh kepemimpinan transaksional terhadap kinerja pegawai yang dimoderasi oleh Locus Of Control mempunyai koefisien jalur sebesar 0,000 mengindikasi bahwa terdapat efek yang lemah.

\section{Pengujian Hipotesis}

Pengujian ini adalah untuk menentukan koefisien jalur dari model struktural. Tujuannya adalah menguji signifikansi semua hubungan atau pengujian hipotesis.

Tabel 5. Path Coefficient

\begin{tabular}{|c|c|c|c|c|c|}
\hline & $\begin{array}{l}\text { Original } \\
\text { Sample (O) }\end{array}$ & $\begin{array}{l}\text { Sample } \\
\text { Mean } \\
(\mathrm{M}) \\
\end{array}$ & $\begin{array}{l}\text { Standard } \\
\text { Error } \\
\text { (STERR) }\end{array}$ & $\begin{array}{l}\text { T Statistics } \\
(\mid \text { O/STERR|) }\end{array}$ & P Values \\
\hline $\begin{array}{l}\text { Moderating Effect } 1 \text {-> } \\
\text { Y }\end{array}$ & $-0,007$ & $-0,030$ & 0,073 & 0,095 & 0,924 \\
\hline $\begin{array}{l}\text { Moderating Effect } 2 \text {-> } \\
\text { Y }\end{array}$ & $-0,008$ & 0,015 & 0,075 & 0,111 & 0,912 \\
\hline X1 -> Y & 0,190 & 0,205 & 0,078 & 2,429 & 0,015 \\
\hline $\mathrm{X} 2$-> Y & 0,353 & 0,352 & 0,071 & 4,961 & 0,000 \\
\hline $\mathbf{Z}->\mathbf{Y}$ & 0,439 & 0,432 & 0,074 & 5,948 & 0,000 \\
\hline
\end{tabular}

\section{Sumber : PLS 3.00} berikut:

Berdasarkan Tabel 5 di atas, dapat dinyatakan bahwa pengujian hipotesis adalah sebagai

1) Pengaruh kepemimpinan tranformasional terhadap kinerja pegawai mempunyai koefisien jalur sebesar 0,190. Ini menunjukkan bahwa jika semakin tinggi tingkat kepemimpinan tranformasional, maka semakin efektif kinerja pegawai Kantor Walikota Medan. Pengaruh tersebut mempunyai nilai probabilitas (p-values) sebesar $0,015<0,05$, berarti pengaruh kepemimpinan transformasional terhadap kinerja pegawai adalah signifikan.

2) Pengaruh kepemimpinan transaksional terhadap kinerja pegawai mempunyai koefisien jalur sebesar 0,353. Ini menunjukkan bahwa jika semakin tinggi tingkat kepemimpinan tranformasional, maka semakin efektif kinerja pegawai Kantor Walikota Medan. Pengaruh tersebut mempunyai nilai probabilitas (p-values) sebesar $0,000<0,05$, berarti pengaruh kepemimpinan transaksional terhadap kinerja pegawai adalah signifikan. 
3) Pengaruh Locus Of Control terhadap kinerja pegawai mempunyai koefisien jalur sebesar 0,439. Ini menunjukkan bahwa jika semakin tinggi tingkat Locus Of Control, maka semakin efektif kinerja pegawai Kantor Walikota Medan. Pengaruh tersebut mempunyai nilai probabilitas (p-values) sebesar $0,000<0,05$, berarti pengaruh Locus Of Control terhadap kinerja pegawai adalah signifikan.

4) Pengaruh kepemimpinan transformasional terhadap kinerja pegawai yang dimoderasi oleh Locus Of Control mempunyai koefisien jalur -0,007 dan mempunyai nilai probabilitas (p-values) sebesar 0,924 > 0,05, hal ini menunjukkan bahwa Locus Of Control tidak signifikan dalam mempengaruhi hubungan antara kepemimpinan transformasional dengan kinerja pegawai. Dengan demikian, variabel Locus of Control tidak memoderasi pengaruh kepemimpinan transformasional terhadap kinerja pegawai pada Kantor Walikota Medan.

5) Pengaruh kepemimpinan transaksional terhadap kinerja pegawai yang dimoderasi oleh Locus Of Control mempunyai koefisien jalur -0,008 dan mempunyai nilai probabilitas (p-values) sebesar 0,912 > 0,05, hal ini menunjukkan bahwa Locus Of Control tidak signifikan dalam mempengaruhi hubungan antara kepemimpinan transaksional dengan kinerja pegawai. Dengan demikian, variabel Locus of Control tidak memoderasi pengaruh kepemimpinan transaksional terhadap kinerja pegawai pada Kantor Walikota Medan.

\section{PEMBAHASAN}

Hasil temuan dalam penelitian ini adalah mengenai hasil temuan penelitian ini terhadap kesesuaian teori, pendapat maupun penelitian terdahulu yang telah dikemukakan hasil penelitian sebelumnya serta pola perilaku yang harus dilakukan untuk mengatasi hal-hal tersebut. Berikut ini ada tiga bagian utama yang akan dibahas dalam analisis hasil temuan penelitian ini, yaitu sebagai berikut:

\section{Pengaruh Kepemimpinan Transformasional Terhadap Kinerja Pegawai}

Dari hasil analisis pengujian hipotesis diketahui bahwa kepemimpinan transformasional berpengaruh positif terhadap kinerja peawai yang dinilai dengan koefisien jalur sebesar 0,190. Nilai probabilitas yang didapatkan adalah sebesar $0,015<0,05$, sehingga H0 ditolak. Hal ini berarti pengaruh variabel kepemimpinan transformasional berpengaruh signifikan terhadap kinerja pegawai Kantor Walikota Medan.

Hal ini menunjukkan bahwa kepemimpinan transformasional mampu meningkatkan kinerja pegawai Kantor Walikota Medan, dimana pemimpin memberi semangat kerja, pemberian nasehat, memotivasi pengembangan kemampuan, pendekatan pada aturan dan prosedur kerja serta memberikan teguran dan pujian kepada anggota organisasi sehingga pegawai akan lebih giat dalam melakukan pekerjaanya sehingga kinerja pegawai tersebut akan semakin meningkat.

Gaya kepemimpinan seorang pemimpin akan diikuti oleh bawahannya, sehingga keberhasilan dalam menjalankan visi dan misi perlu dilakukan peningkatan kualitas sumber daya manusia. Gaya kepemimpinan yang ditampilkan seorang pemimpin yang transformasional diharapkan dapat meningkatkan upaya bawahan untuk mencapai hasil kerja yang optimal. Gaya kepemimpinan transformasional merupakan salah satu gaya kepemimpinan yang mulai diperhitungkan kegunaannya dalam menghadapi perubahan suatu organisasi. Bukti empiris menunjukkan bahwa, praktik gaya kepemimpinan transformasional mampu membawa perubahan-perubahan tersebut yang akan berdampak pada timbulnya motivasi bawahan atau bawahan mampu mempertinggi motivasi untuk melakukan upaya ekstra dalam mencapai kinerja yang diharapkan (Mujiarsih \& Hadi, 2003).

Berkaitan dengan gaya kepemimpinan transformasional yang memberikan dampak pada upaya mencapai kinerja yang lebih baik. Hal ini di dasarkan pada suatu kondisi bahwa, 
keputusan transformasional dibangun atas gagasan-gagasan dari perilaku pemimpin. Tingkat seorang pemimpin disebut transformasional dapat diukur dalam hubungannya dengan efek pemimpin tersebut terhadap bawahan. Kepemimpinan sangat berpengaruh terhadap iklim kerja. Kondisi iklim kerja akan mempengaruhi kondisi motivasi dan semangt kerja anggota. Jika kekuasaan pemimpin sesuai dengan situasi yang dihadapi dalam organisasi atau unit kerja, maka akan membuat iklim kerja menjadi kondusif, dan pada akhirnya akan memberi motivasi yang tinggi bagi anggota untuk memberikan yang terbaik dalam mencapai target kerja (bahkan memberikan extra ordinary atau discretionary effort), sehingga akan tercapai kinerja yang optimal.

Kepemimpinan menunjukkan bahwa proses ini melibatkan kemampuan individu untuk memotivasi dan mempengaruhi orang lain, sementara definisi dasar kepemimpinan secara konsisten telah digunakan sebagai dasar untuk mengevaluasi kepemimpinan, para ahli telah mengembangkan dasar-dasar teori kepemimpinan dalam praktek seperti Sifat, perilaku, situasional, transaksional dan transformasi (Orabi \& Tareq, 2016)

Menurut (Nothouse, 2013) kepemimpinan transformasional adalah Kepemimpinan transformasional yang murni adalah kepemimpinan yang bersifat sosial dan peduli dengan kebaikan bersama. Pemimpin transformasional yang bersifat sosial ini mengalahkan kepentingan mereka sendiri demi kebaikan orang lain. Hasil penelitian ini sejalan dengan hasiul penelitian terdahulu yang dilakukan oleh (Cahyono et al., 2014) (Tucunan et al., 2014) (Amri et al., 2016), (M I Nasution, 2018) dan (Jufrizen, 2017) membuktikan bahwa Kepemimpinan Transformasional memiliki pengaruh yang signifikan terhadap kinerja karyawan.

\section{Pengaruh Kepemimpinan Transaksional Terhadap Kinerja Pegawai}

Dari hasil analisis pengujian hipotesis diketahui bahwa kepemimpinan transaksional berpengaruh positif terhadap kinerja peawai yang dinilai dengan koefisien jalur sebesar 0,353. Nilai probabilitas yang didapatkan adalah sebesar $0,000<0,05$, sehingga $\mathrm{H} 0$ ditolak. Hal ini berarti pengaruh variabel kepemimpinan transaksional berpengaruh signifikan terhadap kinerja pegawai Kantor Walikota Medan. Hal ini menunjukkan bahwa kepemimpinan transformasional mampu meningkatkan kinerja pegawai Kantor Walikota Medan, dimana pemimpin yang mengidentifikasi keinginan atau pilihan bawahan akan membantu pegawai untuk memperoleh arahan dalam melakukan pekerjaan yang memadai, mereka akan dapat melakukan tindakan sesuai dengan arahan sehingga menghasilkan outcome yang diinginkan dan memilih dari kemungkinan berbagai tindakan atau tugas yang diinginkan. Semua ini pada akhirnya akan meningkatkan kinerja pegawai baik secara kualitas maupun kuantitas.

Pola hubungan yang dikembangkan kepemimpinan transaksional adalah berdasarkan suatu sistem timbal balik (transaksi) yang sangat menguntungkan (mutual system of reinforcement) yaitu pemimpin memahami kebutuhan dasar para pengikutnya dan pemimpin menemukan penyelesaian atas cara kerja dari para pengikutnya tersebut. Pemimpin transaksional merancang cara kerja sedemikian rupa yang disesuaikan dengan jenis dan jenjang jabatannya dan melakukan interaksi atau hubungan mutualis. Kepemimpinan Transaksional yang diterapkan oleh seorang pimpinan akan mendorong karyawannya bekerja lebih baik lagi, sehingga program atau sasaran yang telah ditetapkan oleh organisasi akan dapat dicapai. Kinerja karyawan pada dasarnya merupakan ukuran kesuksesan perhitungan hasil akhir atau tingkat pencapaian hasil, baik oleh individu maupun kelompok dalam suatu organisasi untuk mencapai tujuan yang telah ditentukan. Menurut (Siagian, 2014) mengatakan bahwa kepemimpinan transaksional yaitu pemimpin yang memberikan sebuah pertukaran melalui imbalan-imbalan untuk mendapatkan kepatuhan atas apa yang telah mereka lakukan. Hasil penelitian ini sejalan dengan hasil penelitian terdahulu yang dilakukan oleh (Oktora et al., 
2018) dan (Anggini et al., 2018) menyimpulkan bahwa Kepemimpinan Transaksional berpengaruh terhadap kinerja.

\section{Pengaruh Locus Of Control Terhadap Kinerja Pegawai}

Dari hasil analisis pengujian hipotesis diketahui bahwa Locus Of Control berpengaruh positif terhadap kinerja peawai yang dinilai dengan koefisien jalur sebesar 0,439 nilai probabilitas (p-values) sebesar $0,000<0,05$, berarti Locus Of Control berpengaruh signifikan terhadap kinerja pegawai. Hal ini menunjukkan bahwa semakin tinggi Locus Of Control maka semakin meningkat kinerja pegawai pada Kantor Walikota Medan. Dimana pegawai dapat mencari jalan keluar dari permasalahan yang dihadapi, langsung mengarahkan ketika keliatan bingung didalam prosedur yang ada, Ketika ada permasalahan pegawai tidak berhenti untuk mencari alternatif jalan keluar lainnya sehingga kinerja pegawai akan semakin meningkat. Locus of control menurut (Munir \& Mehsoon, 2010) adalah cerminan dari sebuah kecendrungan seorang individu untuk percaya bahwa dia mengendalikan peristiwa yang terjadi dalam hidupnya (internal) atau kendali atas peristiwa yang terjadi dalam hidupnya itu berasal dari hal lain, misalnya kuasa orang lain (eksternal). Hasil penelitian ini sejalan dengan hasil penelitian terdahulu yang dilakukan oleh (Yusneina, 2018), (Hermawan, 2014) dan (Antasurya, 2013) menyimpulkan bahwa Locus Of Control terhadap kinerja pegawai.

\section{Pengaruh Kepemimpinan Transformasional Terhadap Kinerja Pegawai Dimoderasi Locus Of Control}

Dari hasil analisis pengujian hipotesis diketahui bahwa Locus Of Control tidak signifikan dalam mempengaruhi hubungan antara kepemimpinan transformasional dengan kinerja pegawai koefisien jalur -0,007 dan mempunyai nilai probabilitas (p-values) sebesar 0,924 > 0,05, hal ini berarti Locus Of Control tidak memoderasi pengaruh kepemimpinan transformasional terhadap kinerja pegawai pada Kantor Walikota Medan. Hal ini menunjuikkan bahwa Locus Of Control tidak mampu mempengaruhi hubungan antara kepemimpinan transformasional terhadap kinerja pegawai pada Kantor Walikota Medan.

Gaya kepemimpinan transformasional merupakan kepemimpinan yang terkait dengan identifikasi diri yang kuat, penciptaan visi bersama untuk masa depan dan hubungan antara pemimpin dan pengikut berdasar pada suatu hal yang lebih daripada sekedar pemberian penghargaan agar patuh. Pemimpin transformasional mendefinisikan kebutuhan untuk perubahan, menciptakan visi baru, memobilisasi komitmen untuk menjalankan visi dan mentransformasi pengikut baik pada tingkat individual maupun tingkat organisasi. Locus of control menurut (Demirtas \& Güneş, 2012) dapat didefinisikan adalah sebagai kekuatan yang mengendalikan tindakan diri karyawan dan hal-hal yang dilakukan terhadap mereka, selain itu locus of control dianggap sebagai persepsi orang tentang siapa atau apa yang bertanggung jawab atas hasil dari perilaku atau peristiwa dalam kehidupan mereka.

\section{Pengaruh Kepemimpinan Transaksional Terhadap Kinerja Pegawai dimoderasi Locus Of Control}

Dari hasil analisis pengujian hipotesis diketahui bahwa Locus Of Control tidak signifikan dalam mempengaruhi hubungan antara kepemimpinan transaksional dengan kinerja pegawai koefisien jalur -0,007 dan mempunyai nilai probabilitas (p-values) sebesar 0,924 > 0,05, hal ini menunjukkan bahwa Locus Of Control tidak signifikan dalam mempengaruhi hubungan antara kepemimpinan transformasional dengan kinerja pegawai. Dengan demikian, variabel Locus of Control tidak memoderasi pengaruh kepemimpinan transformasional 
terhadap kinerja pegawai pada Kantor Walikota Medan.Hal ini menunjuikkan bahwa Locus Of Control tidak mampu mempengaruhi hubungan antara kepemimpinan transaksional terhadap kinerja pegawai pada Kantor Walikota Medan. Kepemimpinan Transaksional yang diterapkan oleh seorang pimpinan akan mendorong karyawannya bekerja lebih baik lagi, sehingga program atau sasaran yang telah ditetapkan oleh organisasi akan dapat dicapai. Kinerja karyawan pada dasarnya merupakan ukuran kesuksesan perhitungan hasil akhir atau tingkat pencapaian hasil, baik oleh individu maupun kelompok dalam suatu organisasi untuk mencapai tujuan yang telah ditentukan

Locus of control menurut (Munir \& Mehsoon, 2010) adalah cerminan dari sebuah kecendrungan seorang individu untuk percaya bahwa dia mengendalikan peristiwa yang terjadi dalam hidupnya (internal) atau kendali atas peristiwa yang terjadi dalam hidupnya itu berasal dari hal lain, misalnya kuasa orang lain (eksternal).

\section{PENUTUP}

Berdasarkan hasil penelitian dan pembahasan yang telah dikemukakan sebelumnya maka dapat diambil kesimpulan dari penelitian mengenai Pengaruh Kepemimpinan Transformasional dan Kepemimpinan Transaksional terhadap Kinerja Pegawai Dengan Locus Of Control Sebagai Variabel Moderating Pada Kantor Walikota Medan adalah Kepemimpinan transformasional berpengaruh signifikan terhadap kinerja pegawai Kantor Walikota Medan, Kepemimpinan transaksional berpengaruh signifikan terhadap kinerja pegawai pegawai Kantor Walikota Medan, Locus Of Control berpengaruh signifikan terhadap kinerja pegawai pegawai Kantor Walikota Medan, Locus Of Control tidak memoderasi pengaruh kepemimpinan transformasional terhadap kinerja pegawai pada Kantor Walikota Medan dan Locus Of Control tidak memoderasi pengaruh kepemimpinan transaksional terhadap kinerja pegawai pada Kantor Walikota Medan. Berdasarkan kesimpulan diatas, maka dalam hal ini penulis dapat menyarankan hal-hal sebagai berikut : 1) Pemimpin agar lebih memberi semangat kerja, pemberian nasehat serta memotivasi pengembangan kemampuan sehingga kinerja pegawai akan semakin meningkat, 2) Pemimpin agar lebih memberikan arahan terhadap pegawai dalam melakukan pekerjaan sehingga kinerja pegawai lebih meningkat, 3) Pemimpin agar senantiasa memberikan motivasi dengan cara memberikan arahan-arahan yang membangun cara berfikir yang kritis kepada pegawai yang memiliki locus of control agar pegawai bisa meningkatkan kinerjanya.

\section{DAFTAR PUSTAKA}

Achmad, R. R. (2016). Gaya Kepemimpinan: Pendekatan Bakat Situasional. Bandung: ARMICO.

Amri, R. F., Suharmono, \& Rahardja, E. (2016). Pengaruh Kepemimpinan Transformasional Dan Kepuasan Kerja Terhadap Loyalitas Yang Berdampak Pada Kinerja Karyawan Di Perusahaan (Studi Pada PT. Kimia Farma Plant Manufacturing Semarang). Jurnal Bisnis Strategi, 25(1), 36-48.

Anggini, F. A. T., Musadieq, M. A., \& Sulistyo, C. W. (2018). Pengaruh Gaya Kepemimpinan Transaksional Dan Motivasi Kerja Terhadap Kinerja Karyawan (Studi Pada Karyawan Departemen Administrasi Dan Departemen Bengkel, Auto2000 Malang Sutoyo). Jurnal Administrasi Bisnis (JAB), 58(1), 173-180.

April, K. A., Dharani, B., \& Peters, K. (2012). Impact of locus of control expectancy on level of well-being. Review of European Studies, 4(2), 158-179.

Arianty, N. (2015). Pengaruh Kepemimpinan Terhadap Kinerja Karyawan. Jurnal Manajemen Tools, 5(1), 1-16. 
Arianty, N. (2015). Pengaruh Pelimpahan Wewenang dan Koordinasi Kerja Terhadap Pengambilan Keputusan di Perusahaan Asuransi Di Kota Medan. Jurnal Manajemen Tools, 4(2), 80-91.

Ayudiati, S. E. (2010). Analisis Pengaruh Locus of Control Terhadap Kinerja Dengan Etika Kerja Islam Sebagai Variabel Moderating (Studi Pada KaryawanTetap Bank Jateng Semarang). Universitas Diponegoro.

Azwar, S. (2004). Sikap Manusia Teori dan Pengukurannya. Yogyakarta: Pustaka Pelajar.

Bass, M. B., \& Riggio, E. R. (2006). Transactional Leadership. Second Edition. New Jersey: Lawrence Erlbaum Associates, Inc.

Bryman, A. (2012). Social Research Metodh Fourthg Editon. Oxford: Oxford Univery Press.

Cahyono, U. T., Maarif, M. S., \& Suharjono. (2014). Pengaruh Kepemimpinan Transformasional Terhadap Kinerja Karyawan di Perusahaan Daerah Perkebunan Jember. Jurnal Manajemen \& Agribisnis, 11(2), 68-76.

Crider, A. B. (1983). Psychology. Illionis: Foreshman and Company.

Darmadi. (2018). Manajemen Sumber Daya Manusia. Yogyakarta: CV. Budi Utama.

Dharma, A. (2004). Manajemen Supervisi. Jakarta: Rajawali Pers.

Falikhatun. (2003). Pengaruh Budaya Organisasi, Locus of Control Dan Penerapan System Informasi Terhadap Aparat Unit-Unit Pelayanan Publik. Emprikas, 16(2), 263-281.

Ghozali, I. (2016). Aplikasi Analisis Multivariete Dengan Program IBM SPSS 23. Semarang: Badan Penerbit Universitas Diponegoro.

Hamedoglu, M., Kantor, J., \& Gulay, E. (2012). The effect of Locus of Control and culture on leader preferences. International Online Journal Of Educational Sciences, 1(4), 319-324.

Handoko, \& Hanny, T. (2013). Manajemen Personalia dan Sumber Daya Manusia. Jakarta: Salemba Empat.

Jufrizen, J. (2017). Efek Moderasi Etika Kerja Pada Pengaruh Kepemimpinan Transformasional dan Budaya Organisasi Terhadap Kinerja Karyawan. E-Mabis : Jurnal Ekonomi Manajemen Dan Bisnis, 18(2), 145-158. https://doi.org/10.29103/e-mabis.v18i2.180

Juliandi, A., Irfan, I., \& Manurung, S. (2015). Metode Penelitian Bisnis : Konsep \& Aplikasi. Medan: UMSU Press.

Kartini, K. (2010). Pemimpin dan Kepemimpinan. Jakarta: PT. Raja Grafindo Persada.

Kutanis, O., Mesci, M., \& Ovdur, Z. (2011). The effects of locus of control on learning performance: A case of academic organization. Journal of Economic and Social Studies, $1(2), 11-36$.

Lensufiie, T. (2010). Leadership untuk Profesional dan Mahasiswa. Jakarta: Erlangga.

Mangkunegara, A. A. (2014). Evaluasi Kinerja Sumber Daya Manusia. Bandung: Refika Aditama.

Muis, M. R., Jufrizen, J., \& Fahmi, M. (2018). Pengaruh Budaya Organisasi Dan Komitmen Organisasi Terhadap Kinerja Karyawan. Jesya (Jurnal Ekonomi \& Ekonomi Syariah), $1(1), 9-25$.

Mujiarsih, E., \& Hadi, S. (2003). Persepsi Mengenai Gaya Kepemimpinan Transformasional dan Transaksional dan Pengaruhnya Terhadap Upaya Ekstra (Extra Effort) Pegawai Dinas Kesehatan Kota (DKK) Semarang, Salatiga dan KabupatenSemarang di Ungaran. Jurnal Bisnis Dan Ekonomi, 10(2), 1-10.

Munir, S., \& Mehsoon, S. (2010). Examining Locus of Control (LOC) as a Determinant of Organizational Commitment among University Professors in Pakistan. Journal of Business Studies Quarterly, 1(3), 1-19. 
Nasution, M I. (2018). Peran Kepuasan Kerja Dan Kepemimpinan Transformasional Terhadap Kinerja Karyawan. Prosiding The National Conferences Management and Business (NCMAB), 425-439.

Nasution, M. I., Fahmi, M., Jufrizen, J., Muslih, M., \& Prayogi, M. A. (2020). The Quality of Small and Medium Enterprises Performance Using the Structural Equation Model-Part Least Square (SEM-PLS). Journal of Physics: Conference Series, 1477(2020), 1-7. https://doi.org/10.1088/1742-6596/1477/5/052052

Nothouse, P. G. (2013). Leadership: Theory and Practicfe. Caliornia: Sage Publication Inc.

Oktora, J., Rizan, M., \& Situngkir, S. (2018). Pengaruh Gaya Kepemimpinan Transaksional Dan Transformasional, Motivasi Serta Kompetensi Terhadap Kinerja Karyawan PT. Sanjayatama Lestari. Jurnal Dinamika Manajemen Dan Bisnis, 1(1), 41-64.

Orabi, \& Tareq, G. A. (2016). The Impact of Transformational Leadership Style on Organizational Performance: Evidence from Jordan. International Journal of Human Resource Studies, 6(2), 89-102.

Purnamie, T. (2014). Peranan Organizational Citizenship Behavior (OCB) Dalam Meningkatkan Kinerja Karyawan. Jakarta: Mitra Wacana Media.

Rivai, V. (2014). Manajemen Sumber Daya Manusia Untuk Perusahaan (6th ed.). Jakarta: PT. Raja Grafindo Persada.

Robbins, S. P. (2012). Perilaku Organisasi. Jakarta: PT. Indeks Kelompok Gramedia.

Rotter, J. B. (2009). Generalized Expectancies For Internal Versus External Control Of Reinforcement. Psychological Monographs, 1(80), 1-18.

Sartika, D. (2014). Pengaruh Kepuasan Kerja dan Gaya Kepemimpinan Transformasional Terhadap Keinginan Keluar Karyawan Dengan Komitmen Organisasi Sebagai Variabel Mediasi (Studi Kasus Di CV. Putra Tama Jaya. Management Analysis Journal, 3(2).

Setiawan, B., \& Muhith, A. (2013). Transformasional Leadership: Ilustrasi di Bidang Organisasi Pendidikan. Jakarta: Rajawali Pers.

Siagian, S. P. (2014). Manajemen dan Evaluasi Kinerja. Jakarta: Bumi Aksara.

Sugiyono. (2018). Metode Penelitian Kuantitatif, Kualitatif dan R\&D. Bandung: Alfabeta.

Susanto, Y. (2017). Peran Kepemimpinan Dalam Pengelolaan Koperasi. Yogyakarta: Deepublish.

Sutrisno, E. (2010). Manajemen Sumber Daya Manusia. Jakarta: Erlangga.

Thomas, K. W., \& Velthouse, B. A. (2003). Cognitive Elements of Empowerment: an Enterpretative Model of Intrinsic Task Motivation. Academy of Management Review, 1(15), 4-16.

Tucunan, R. J. A., Suprtha, W. G., \& Riana, I. G. (2014). Pengaruh Kepemimpinan Transformasional Terhadap Motivasi Dan Kinerja Karyawan (Sudi Kasus Pada PT. Pandawa). E - Jurnal Ekonomi Dan Bisnis Universitas Udayana, 3(9), 533-550.

Wahab, A., \& Umiarso. (2011). Kepemimpinan Pendidikan dan Kecerdasan Spiritual. Yogyakarta: Ar-Ruzz Media.

Wibowo, W. (2010). Manajemen Kinerja. Jakarta: Rajawali Pres.

Yukl, G. (2010). Kepemimpinan Dalam Organisasi. Jakarta: PT. Indeks Kelompok Gramedia. 